\title{
Social Semiotics: Realizing Destination Image by Means of Cultural Representations
}

\author{
Hanita Hassan
}

\begin{abstract}
This paper discusses the ways in which cultures are used as a part of tourism commodities to realize destination image. Tourism advertisements were analyzed using multimodal discourse framework. The findings show that both, linguistic and nonlinguistic, modes complement each other as social semiotic resources in realizing cultures as destination image. Different ethnic groups that reside in Malaysia and traditional lifestyles which compose Malaysian cultures are linguistically described as to instill the sense of pleasure, impressiveness and recreational. On the other hand, images that portray Malaysian cultures, for example, people from different ethnicities, traditional costumes and traditional houses are found to be exclusively adopted in tourism advertisements as persuasive tools.
\end{abstract}

Index Terms-Culture, meaning making. social semiotics, tourism advertisements.

\section{INTRODUCTION}

Tourism is defined as leisure and recreational purpose activities, which involve long or short journeys and temporary stays of the trip [1], [2]. Having realized the importance of tourism industry, which has turned up to be one of the global largest economic sectors, Malaysia Tourism Board, as a responsible agency in promoting Malaysia, has planned tourism activities well, for instance, Visit Malaysia Year 2014. This is to ensure that Malaysia stays as one of the top chosen destinations.

To be competitive in the tourism industry, Malaysia has to diverse its commodities. A study done on Malaysian tourism discourse has found that Malaysian tourism commodities which are highlighted in tourism brochures are of various types, for instance, exciting tourist destinations, natural wonders, shopping paradise, a place for a gastronomic adventure, exciting choices of entertainment and lastly a fascinating diversity of cultures [3]. Culture is one of the promising commodities in tourism industry since current tourists expect to experience the culture of the visited region in which tourism provides genuine, meaningful interactions between cultures [4].

This thus means that the tradition of one's identity and culture can be sustained by means of tourism industry when identity and culture are the objects of tourism [5]. Having said that, this is the reason for Malaysia to experience cultural hybridization, or in other words, tourism activities have lead to a situation in which multiple cultures of Malaysia are combined to form a unique culture [6].

Manuscript received October 2, 2013; revised December 4, 2013.

Hanita Hassan is with the Language Academy, Universiti Teknologi Malaysia (e-mail: hanita@utm.my).
However, studies on tourism from a communication perspective are lacking [7] and therefore this study aimed to study how Malaysian diverse cultures are represented to realize a destination image using social semiotic framework.

\section{Social Semiotics as a Meaning MaKing Tool}

\section{A. Semiotic Resources}

Social semiotics refers to social or semiotic actions that produce meaning. The main concern of social semiotics is on the construction of social meaning, or a common theme, by means of semiotic forms, for instance, texts and practices [8], [9]. In order to derive to the shared meaning, the society needs to get hold of certain semiotic resources.

Semiotic resources include almost everything we do or make that contributes to meaning and this thus makes it clear that 'semiotic resources are not restricted to speech and writing and picture making'. In other words, social semiotics is about how we use semiotic resources to produce meaning [10]. Given the fact that the data of this study were tourism promotional tools or advertisements, therefore the common semiotic resources dealt in this study were high level of words and attractive visual images.

Following [8], society in this study is the domain of action, whilst culture is the semiotic resources. This is to say that culture is the repository of resources which are used as a tool by the society or a group for making potential meanings.

\section{B. Semiotic Analysis of Tourism Discourse}

The term discourse refers to 'an extended stretch of connected speech or writing, a text' [11]. In this study, the data used were tourism promotional tools or advertisements produced by Malaysian Tourism Board (MTB). The main goal of tourism advertisements is to portray the beautifulness and uniqueness of a certain place [12], [6]. In addition, the function of language in any tourism advertisement materials is to lead tourists to contextualize experience towards the destination [13]. Tourism advertisements, which are used as a promotional tool, are therefore a type of texts, or in other words, a discourse.

It is interesting to investigate tourism discourse from a social semiotic perspective. This is because tourism discourse is the result of social actions and furthermore it employs specific terminology, for instance, specific lexical, syntactical and textual features [14]. These structures have in turn classified tourism discourse as a specialized discourse in which language or linguistic mode and images or nonlinguistic mode are used as semiotic resources for meaning making [2], [15].

Having said that the functions of current tourism 
advertisements are not limited to providing information on spectacular tourism destinations for example, resorts and theme parks as tourism attractions, on the other hand, culture is becoming the pivotal commodity of tourism industries. Given the fact that Malaysia comprises of different races and ethnicities, it is obvious that Malaysia cultural diversity has remarkably become the impetus for the tourist attractions besides its picturesque destinations.

Nevertheless, the study on how Malaysian cultures are portrayed and represented as tourism commodities from semiotic perspective is lacking. This paper thus aims to discuss the ways in which different semiotic resources are employed in tourism advertisements in representing Malaysian cultures to realize destination image.

\section{Destination IMAgE}

In marketing strategy, the most important component is product positioning, by which the product image is created and exaggerated in the consumers' mind. Even multinational corporations also create the company image, which normally informs customers who they are, what they do and what they have [16]. Similar to tourism industry, the most important component in this business is to create the desire image in tourists' mind. However, the product in the tourism business is destination, it is therefore crucial for this industry to create and manage destination image that suits effective marketing strategy [17].

Destination image can be defined as the mental representation of knowledge (belief), feelings and perceptions of a tourism destination [18], [19]. There are five factors that influence tourists' experience expectations, and experience expectation is gained through tourism promotional tools before the trip. The five factors are easiness and fun, cultural entertainment, personal identification, historical reminiscences and lastly escapism [20]. The focus of this paper is however on the tourists' experience expectations, which are gained before the trip by means of promotional tools and, on top of that, culture as the tourism commodity, of which it is claimed that 'tourists are pleasantly moved by different cultures' [21].

\section{Methodology}

This study employed multimodal discourse which aimed to investigate the realization of destination by means of culture representations. The data were Malaysian tourism promotional tools or advertisements, for example, tourist guides, tourism brochures and websites, featuring Malaysia, Penang, Malacca and Sarawak. Penang and Malacca were chosen since both states were declared as the World Heritage Site by UNESCO in 2008. Sarawak, in addition, was chosen due to its richness in multi-cultural heritage.

This study was interested to investigate the ways in which the promotion of Malaysian cultures in the tourism advertisements can be construed as destination image. The aims of this study among others were i) to explore the roles of multimodal semiotic modes in representing Malaysian diverse cultures, and ii) to analyse the ways in which represented Malaysian cultures in tourism advertising can be construed as Malaysian destination image.

It is interesting to see how the different semiotic modes can be juxtaposed in meaning making process. The findings of a study on corporate websites show that different semiotic modes are employed by multinational corporations in disseminating information to their customers, and it is found that both, linguistic and non-linguistic, modes complement each other as a persuasive tool [16]. In this study, taking into account of the occurrence of different semiotic modes in the texts, the data were therefore analyzed using the theory of multimodal discourse [22], [23].

\section{Using CUltural REPRESENTATIONS TO REALIZE DESTINATION IMAGE}

\section{A. Realizing Destination Image by Means of Linguistic Mode}

As mentioned earlier the trend now is that the aim of tourists is to experience the genuine culture of others, that is, the culture of the visited destination [4]. This interest has influenced the way in which tourism advertisements are written, for instance, Extract 1 obviously tries to attract tourists by promising an invaluable cultural experience. This can be seen from the first clause which starts of experience local culture, customs and traditions.

- Extract 1

- Fascinating Cultures

- Experience local culture, customs and traditions in a homestay village. Stay at a traditional dwelling - a traditional Malay house or an ethnic community's longhouse - in the midst of natural surroundings, away from the hustle and bustle of the concrete jungle. If your stay coincides with a major cultural festival, you also get to join in the celebrations and experience the spirit of festivities the Malaysian way! Enjoy dance moves or how to play traditional musical instruments. Some homestays even hold mock weddings, showcasing the many facets of local traditions and customs.

The function of the words used, for instance, local culture, customs and traditions, a traditional Malay house, an ethnic community's longhouse, cultural festival and traditional musical instruments, is to promote the Malaysian cultures as the tourism commodity. As a result, this can be indirectly construed as the destination image of Malaysia, of which cultural entertainment is one the factors to influence tourists' experience expectations [20]. It is thus pivotal for the language used to enable tourists to contextualize experience towards the destination [13].

Most importantly to highlight that Malaysia has diverse cultures, the multiethnic society is excessively emphasized [27]. This is because each ethnic group has its own culture which can be similar or totally different from others. Extract 2 which is taken from the tourist guide book of Sarawak, for example, entails information on different ethnic groups found in Sarawak.

- Extract 2

- The People: A Land of Cultural Contrast

- Sarawak is a melting pot of over 27 indigenous groups, 
Malays and native Chinese descendants of immigrants from centuries back. Over 40 languages and dialects are spoken here.

- The Iban live by the coast and were once head-hunters. They are the most populous group. The Bidayuh live further inland and are a brave and warrior-like people.

- The Orang Ulu are a group of different peoples who live in the upper reaches of the great rivers. They include the Kayan, Kenyah, Kelabit, Lun Bawang, Lun Dayeh, Penan, Sab'n and many more. Theirs are gentle cultures with hierarchies of aristocracies and nobility.

- The Malay lived by the coast and are the third most populous group. Many still make a living as fishermen.

- The Chinese are the second most populous after the Iban. The earliest record of trade between Sarawak and China dates back almost 600 years. The oldest families have been here for at least 150 years. Indigenous Chinese culture in Sarawak has evolved its own local nuances and rhythm.

- Intermarriages are well accepted and common without diluting cultures. This is one of Sarawak's many characteristics that make it an intriguing place to visit.

The title of Extract 2 which is a land of cultural contrast overtly portrays the diversity of Sarawak cultures and the meaning is accentuated by the words over 27 indigenous groups in the first paragraph. The words also signify the richness of Sarawak cultures since, as mentioned earlier, each ethnic group has its own culture and there are 27 indigenous groups with their own cultures. Furthermore, the clause Over 40 languages and dialects are spoken here, foreground the meaning of diverse cultures. This is due to the fact that interaction is the foundation of meaning-making and can therefore be regarded as one of 'shared cultural resources' in the community [8], by which means language used in interaction is part of one's culture.

Some of the ethnic groups mentioned in the text are Iban, Bidayuh, Malays, Orang Ulu and Chinese. The information on traditional lifestyle of each ethnic group is provided, for instance, Iban were head-hunters, Bidayuh were brave and warrior-like people, Malays lived as fishermen and Chinese were traders. The traditional living style is one of the cultural elements found in the tourism advertisements, this is because the way of living of a certain community is part of the social semiotic resources and in turn can be construed as one's culture [27].

The findings show that the description of traditional lifestyle includes traditional dwelling, or in other words, traditional houses of different ethnic groups. For instance, the traditional house of the Penang Peranakan is well described in Extract 3.

- Extract 3

- The Penang Peranakan Mansion is a stately mansion, refurbished to reflect bygone days of the Straits Chinese settlement in Penang.

- This magnificent townhouse is the former residence and office of Chine Kapitan Chung Keng Kwee. He was a 19th century Hakka tin-miner and secret society leader of Hai San.

- The Penang Peranakan Mansion is filled with more than 1,000 antiques and collectibles. The residence is unique and incorporates various Chinese architecture.

- The townhouse, built in 1890s incorporates Chinese carved-wood panels, with English floor tiles and Scottish iron works.

The words used in Extract 3 that trigger the meaning of culture are Penang Peranakan, a special community which is also known as Straits Chinese. The majority of Straits Chinese live in Malacca. Other words are, for example, 1,000 antiques and collectible, Chinese architecture, built in 1890s and Chinese carved-wood panels. These words signify the traditional houses of Penang Peranakan. Reading the extract will help readers to construe the type and the design of traditional Straits Chinese dwellings.

The language of tourism discourse entails the sense of pleasure, impressiveness and recreational [24]. Following this, the findings of the analysis done on the three extracts mentioned in this section show that the tourism advertisements work on to instill the feeling of pleasure, impressiveness and recreational by highlighting the significant diverse cultures of Malaysians by means of portraying multiethnic society, different languages, traditional lifestyles and traditional house architecture of different ethnic groups.

\section{B. Realizing Destination Image by Means of Nonlinguistic Mode}

Malaysia's population is 28.8 million, of which 51 per cent are Malays, followed by Chinese 23 per cent, natives of Sabah and Sarawak take up 11 per cent, Indian 7 per cent and others are about 8 per cent [28]. In relation to this, the function of Fig. 1 is apparently to foreground different ethnic groups of Malaysia in their traditional costumes. Similar to language, a traditional costume is an identity signifier and more interestingly, costumes are frequently used to represent one's ethnic culture. It requires the shared social knowledge about traditional costumes before one is be able to differentiate different ethnic groups. This is to say that traditional costumes are construed as one of social semiotic resources which determines one's culture.

Given the fact that Malays are the majority, which is $51 \%$ of the population, and Malays are the original inhabitants of Malaysia, the couple in Malay traditional costumes are therefore placed in the centre (refer to Fig. 1) to mean salience (Hassan, 2012; Kress and Van Leeuwen, 1996).

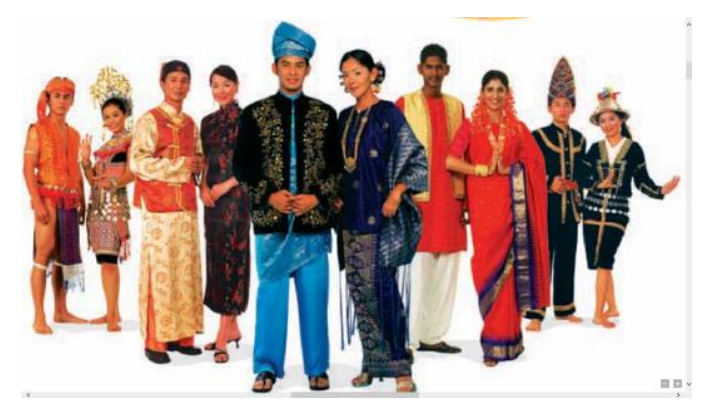

Fig. 1. Various ethnic groups in Malaysia.

The image of the Malay couple is followed by a Chinese (on the left) and Indian (on the right) couples. This thus signifies that Chinese is the second largest ethnic group and followed by Indians. Whilst the last two couples are the 
representative of ethnic groups from Sarawak on the left and Sabah on the right.

Malaysian traditional houses are not only described linguistically, but the images of traditional houses are also included in the tourism promotional tools. Certain information is best delivered by means of image then words [16]. This is true with traditional houses, of which linguistic description alone will make it difficult for readers to decipher. Fig. 2 is an illustration of traditional Malay houses.

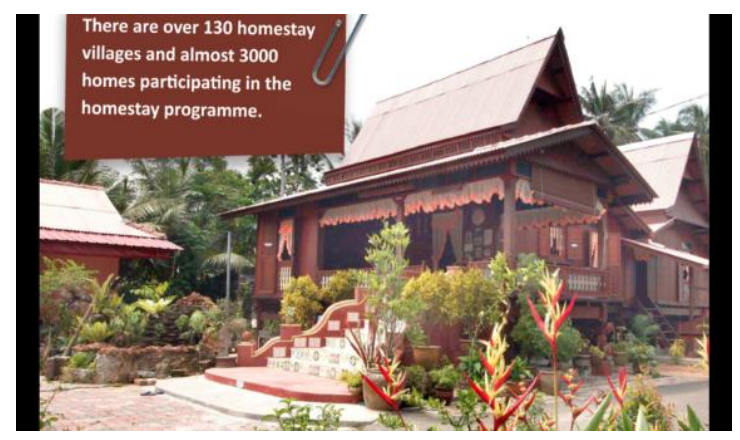

Fig. 2. Traditional Malay house.

The traditional Malay houses, or, also called kampung houses, are commonly made of wood or any materials which are available from the tropical forests, for instance, timber, bamboo, rattan, tree roots and leaves. Another common feature of traditional Malay houses is an open interior space or verandah which is good for ventilation, lighting and the full use of space purposes. Interestingly, the shapes and sizes of kampung houses differ from state to state [25], [26]. Even though it is easy for Malaysians to recognize the Malay houses (Fig. 2) due to the shared social semiotic resources, it might not be feasible for foreigners. The reason behind this is the factor of insiders, who are part of a certain community or society that shares the same culture or repository of semiotic resources [8].

Festivals or celebrations are also part of cultural elements [27]. Fig. 3, for example, illustrates the Chingay festival which is celebrated in Penang. The Chingay procession is held every year during Chinese New Year and Pesta Pulau Pinang.

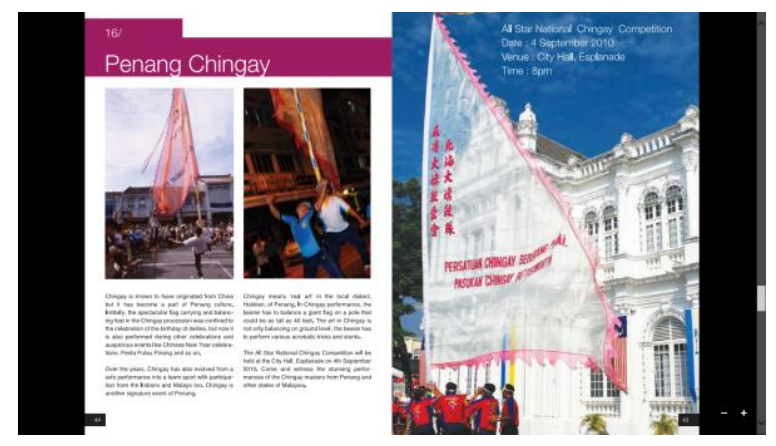

Fig. 3. Penang Chingay procession.

Similar to the design of traditional Malay houses, most Malaysians as insiders can tell from the image it is a Chingay procession and normally held in Penang. Chingay is part of Chinese culture which is originated from China. The earliest settlement of Chinese was during the diplomatic relation between China and Malacca, by which China provides protection for the safety of the Malacca straits against Siam and Majapahit.

Images play a pivotal role in delivering messages to tourists in tourism promotional tools. As mentioned earlier, there is certain information cannot be delivered by means of words. The findings of this study show that linguistic and nonlinguistic modes are complementing each other as social semiotic resources in realizing culture as a destination image.

\section{CONCLUSION}

In summary, culture is part of social semiotic resources that is used as a tool for meaning making. Interestingly, culture is also employed as a tourism commodity in realizing destination image. One of the aims of promoting one's culture is to provide potential tourists with experience expectation so that they can expect to experience the meaningful trip [4], [20].

\section{ACKNOWLEDGMENT}

I would like thank Ministry of Higher Education (MOHE), Malaysia and Research Management Centre, Universiti Teknologi Malaysia for the research fund under Exploratory Research Grant Scheme R.J130000.7841.4L079.

\section{REFERENCES}

[1] D. Dredge and J. Jenkins, Tourism Planning and Policy, Australia: John Wiley and Son. J, 2007.

[2] J. Urry, The Tourist Gaze, 2nd ed. London: Sage, 2002.

[3] H. Hassan, H. Habil, and Z. M. Nasir, "Persuasive strategies of tourism discourse," in New Perspectives in Language and Communication Research, H. Habil and H. Hassan, Eds. Johor: UTM Press, 2008, pp. $1-19$.

[4] C. Rojek and J. Urry, Touring Culturess: Transformation of Travel and Theory, London: Routledge, 1997.

[5] C, Palmer, "Tourism and the symbols of identity," Tourism Management, vol. 20, pp. 313-321, 1999.

[6] T. Endesor, "Performing tourism, staging tourism: $(\mathrm{Re})$ producing tourist space and practice," Tourist Studies, vol. 1, no. 1. pp. 59-81, 2001.

[7] M. A. Salim, N. A. Ibrahim, and H. Hassan, "Language for tourism: A review of literature," Procedia: Social and Behavioral Sciences, vol. 66, pp. 136-143, 2012.

[8] G. Kress, "Thinking about the notion of 'cross-cultural' from a social semiotic perspective," Language and Intercultural Communication, vol. 12, no. 4, November 2012.

[9] T. V. Leeuwen, Introducing Social Semiotics, London: Routledge, 2005, ch. 1, pp. 4.

[10] R. Hodge and G. Kress, Social Semiotics, NY: Cornell University Press, 1988.

[11] T. V. Leeuwen, Introducing Social Semiotics, London: Routledge, 2005, ch. 5, pp. 94.

[12] C. Aitchison, "Theorizing other discourses of tourism, gender and culture," Tourists Studies, vol. 1, no. 2. pp. 133-147, 2001.

[13] G. M. S. Dann, The Language of Tourism: A Sociolinguistic Perspective, Wallingford: CAB International, 1996.

[14] I. D. Muńoz, "Tourist translation as a mediation tool: misunderstandings and difficulties," Cadernos de Traducáo, vol. 1. no. 27, pp. 29-47. 2011.

[15] A. Jaworski and A. Pritchard, Discourse, Communication and Tourism, UK: Channel Publication, 2005.

[16] H. Hassan, Multimodal Communication of Corporate Website Design, Malaysia: UTM Press, 2012.

[17] C. M. Echtner and J. R. B. Ritchie, "The measurement of destination image: An empirical assessment," Journal of Travel Research, vol. 31, no. 3, pp. 3-13, April 1993.

[18] J. Crompton, "An assessment of the image of Mexico as a vacation destination and the influence of geographical location upon the image," Journal of Travel Research, vol. 12, no. 4, pp. 18-23, 1979. 
[19] P. Fakeye and J. Crompton, "Image differences between prospective, first-time, and repeat visitors to the Iower Rio Grande valley," Journal of Travel Research, vol. 30, no. 2, pp. 10-16.

[20] S. C. Wen and C. M. Chia, "Tourist experience expectations: questionnaire development and text narrative analysis," International Journal of Culture, Tourism and Hospitality Research, vol. 7, no. 1, pp. 93-104, 2013.

[21] S. C. Wen and C. M. Chia, "Tourist experience expectations: questionnaire development and text narrative analysis," International Journal of Culture, Tourism and Hospitality Research, vol. 7, no. 1, pp. 93-104, 2013, pp. 100.

[22] G. Kress and T. V. Leeuwen, Multimodal Discourse: The Modes and Media of Contemporary Communication, London: Arnold, 2001.

[23] K. L. O'Halloran, "Visual semiosis in film," in Multimodal Discourse Analysis: Systemic-Functional Perspectives, K. L. O'Halloran, Ed. London: Continuum, 2004, ch. 5, pp. 109-130.

[24] A. G. Stamous and S. Paraskevopoulous, "Images of nature by tourism and environmentalist discourses in visitor books: A critical discourse analysis of ecotourism," Discourse Society, vol. 15, no. 1, pp. 105-129.

[25] J. Y. Lim. (November 2013). The traditional Malay house. [Online]. Available: http://www.sabrizain.org/malaya/library/malayhouse.pdf

[26] A. G. Ahmad. (November 2013). Malay vernacular architecture. [Online]. http://www.hbp.usm.my/conservation/malayvernacular.htm

[27] H. Hassan, "The representation of Malaysian cultures in tourism brochures," Procedia: Social and Behavioral Sciences, In print.

[28] Department of Statistics Malaysia. (April 2012). [Online]. Available: http://www.statistics.gov.my

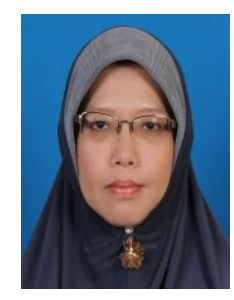

Hanita Hassan was born in Penang, Malaysia on May 14, 1966. She was conferred with Ph.D. in Language and Communication from Cardiff University, UK in 2006. Besides, she also obtained her MSc TESP (Teaching English for Specific Purposes) from Aston University, UK in 1993. She did B.Sc Science with Education (Honours) with major in Mathematics at Universiti Teknologi Malaysia from 1984 to 1989 . Hanita is currently a senior lecturer at Language Academy, Universiti Teknologi Malaysia (UTM). She has joined UTM right after her graduation in 1989. She teaches several subjects besides proficiency courses. Currently she is teaching Language Teaching Methodology to M.Ed TESL students. She is also supervising masters of Philosophy (MPhil), M.Ed TESL and Ph.D students. She has published several books, among others include Multimodal Communication of Corporate Website Design (Skudai, Johor Bahru: UTM Press, 2012), New Perspectives in Language and Communication Research (Skudai, Johor Bahru: UTM Press, 2008) and English for Career Search (Selangor: Prentice Hall, 2008). Her research interests include Systemic Functional Linguistics, Multimodal Discourse and Language Teaching Methodology. Dr. Hassan is a member of ISFLA (International Systemic Functional Linguistic Association) and IATEFL (International Association of Teaching English as Foreign Language). She received excellent academic staff awards in 2008 and 2013. She has also won The Original Book Award from UTM in 2013. She is in the editorial board for ESP Malaysia Journal and reviewed several papers written in the area of language and communication and language teaching. Hanita can contacted at hanita@utm.my, telephone 6075531828 or mobile 60197749070. 